\title{
Mantle cell lymphoma with diminished expression of B-cell antigens: an unusual presentation
}

\author{
Harpreet Virk, ${ }^{1}$ Sreejesh Sreedharanunni (D) ,' Man Updesh Singh Sachdeva, \\ Ashim Das ${ }^{2}$
}

'Department of Hematology, Postgraduate Institute of Medical Education and Research, Chandigarh, India ${ }^{2}$ Department of Histopathology, Postgraduate Institute of Medical Education and Research, Chandigarh, India

\section{Correspondence to} Dr Sreejesh Sreedharanunni; dr.s.sreejesh@gmail.com

Accepted 24 June 2020
D) Check for updates

(c) BMJ Publishing Group Limited 2020. No commercial re-use. See rights and permissions. Published by BMJ.

\footnotetext{
To cite: Virk $H_{\text {, }}$

Sreedharanunni $S$,

Sachdeva MUS, et al. BMJ

Case Rep 2020;13:e235561.

doi:10.1136/bcr-2020-

235561
}

\section{DESCRIPTION}

A 64-year-old diabetic male presented with generalised weakness for 2 months. On evaluation, he had pallor, generalised lymphadenopathy and mild splenomegaly. Peripheral blood (PB) showed anaemia (haemoglobin $84 \mathrm{~g} / \mathrm{L}$ ), leucocytosis (total leucocyte count $17.1 \times 10^{9} / \mathrm{L}$ ), lymphocytosis (absolute lymphocyte count $5.8 \times 10^{9} / \mathrm{L}$ ) and thrombocytopenia (platelet count $111 \times 10^{9} / \mathrm{L}$ ). Bone marrow (BM) examination revealed predominantly atypical small-sized lymphoid cells (92\%) (figure 1A-B) that on multicolour flow cytometry were CD $19^{\text {bright }}, \mathrm{CD} 5^{\text {bright }}, \mathrm{CD} 20^{\mathrm{dim}}, \mathrm{CD} 79 \mathrm{~b}^{\mathrm{dim}}$, CD22 $2^{\text {dim }}, \operatorname{IgM}^{\text {moderate }}, \mathrm{IgD}^{\text {moderate }}, \mathrm{CD} 43^{\mathrm{dim}}$, $\mathrm{FMC}^{\text {negative }}, \mathrm{CD} 200^{\text {negative }}, \mathrm{CD} 23^{\text {negative }}$ and surface light chain $^{\text {negative }}$ (figure 1C). Diagnosis of chronic

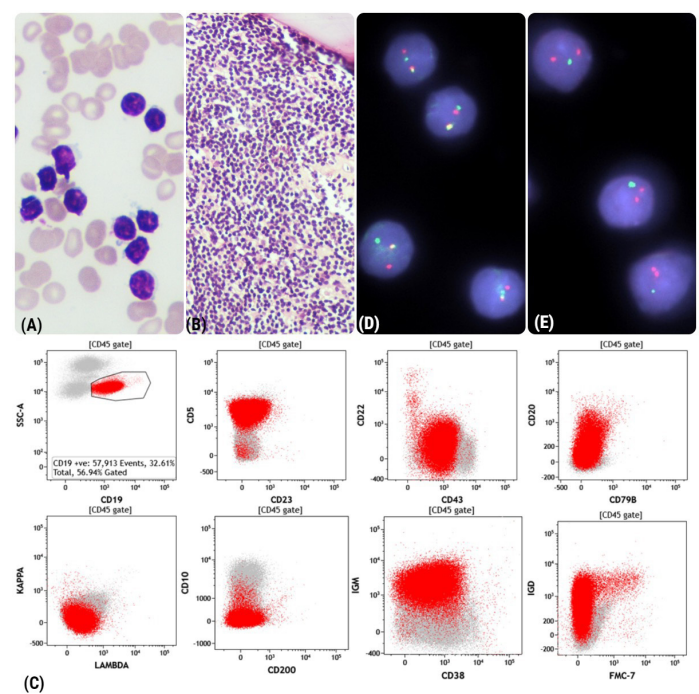

Figure 1 ( $A, B)$ Bone marrow aspirate and biopsy show atypical lymphoid cells with variably clumped nuclear chromatin, predominantly regular nuclear contours and scant cytoplasm (May-Grünwald Giemsa stain; $\times 200$ and H\&E stain; $\times 400$, respectively). (C) Flow cytometry shows CD5 bright $, C D 20^{\text {dim }}, C D 79 b^{\text {dim }}, C D 22^{\text {dim }}, F^{\text {bC }} 7^{\text {neg }}$, surface light chain ${ }^{\text {neg }}, \operatorname{lgM}^{\text {moderate }}, \lg ^{\text {moderate }}, C^{\prime} 200^{\text {neg }}$ immunophenotype; fluorescence in-situ hybridisation (FISH) testing shows positivity for (D) cyclin D1/CCND1 translocation and (E) $/ g H$ translocation of one allele with deletion of variable gene segment on the telomeric side of other $\mathrm{IgH}$ allele (Vysis dual-colour break-apart probes; Abbott, USA). This pattern does not entirely exclude a biallelic $\mathrm{lgH}$ translocation, even though the second partner is unknown in our case. The cells were also negative for $B C L 2$ and $B C L 6$ translocations as well as TP53 and ATM gene deletions (not shown).

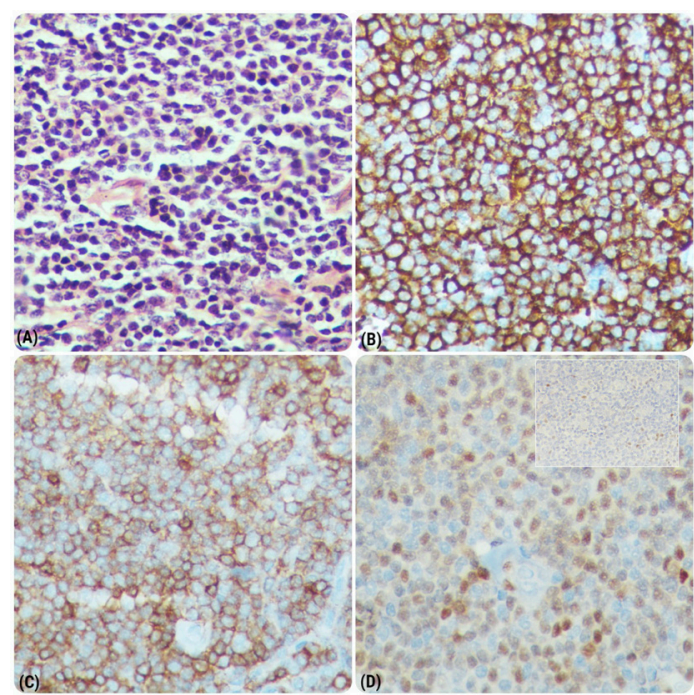

Figure 2 Lymph node biopsy showing (A) diffuse effacement of nodal architecture by sheets of small-sized lymphoid cells $(\times 400)$. (B-D) Cells express CD20, CD5 and cyclin D1. They were also positive for BCL2 and negative for CD23 (not shown) and SOX-11 (<10\% positivity; inset).

lymphocytic leukaemia (CLL) or atypical CLL was initially considered. However, due to subtle atypical features (CD23 $\left.3^{\text {negative }}, \mathrm{CD} 200^{\text {negative }}, \mathrm{CD} 43^{\text {dim }}\right)$, fluorescence in-situ hybridisation (FISH) testing was advised. FISH revealed $I g H$ and cyclin D1/ CCND1 translocation in 90\% cells (figure 1D-E). A lymph node biopsy confirmed the diagnosis of SOX-11-negative mantle cell lymphoma (MCL) (figure 2). Renal biopsy for the evaluation for renal dysfunction (serum creatinine $283 \mu \mathrm{mol} / \mathrm{L}$ ) revealed diabetic nephropathy as well as infiltration by MCL. He was counselled for chemoimmunotherapy (bendamustine and rituximab); however, he declined treatment and stopped hospital visits due to financial reasons. A telephonic follow-up 11 months after the initial diagnosis revealed that his condition is stable and although he continues to experience fatigue, but is still not on any specific therapy.

Flow cytometry represents an invaluable tool for the diagnosis of mature $\mathrm{B}$-cell neoplasms (MBN) infiltrating $\mathrm{PB}$ or $\mathrm{BM}$. In the presence of typical CLL immunophenotype (bright CD5, dim CD20 and surface immunoglobulins), haematopathologists may render a diagnosis of CLL without any further work-up. Unlike CLL, virtually all other CD5+veMBNs including MCL show bright 
expression of pan-B-cell antigens (CD19, CD20 and CD22). ${ }^{1}$ However, variations from typical immunophenotype have been observed, some of which could be misleading and cause diagnostic difficulties. Atypical immunophenotypic features in CLL include CD23 negativity, dim/negative CD5, expression of FMC7 and strong expression of surface immunoglobulins. ${ }^{2}$ MCL has been reported to show variations like CD5 and FMC7 negativity, or CD10 and CD23 positivity. ${ }^{3}$ Our patient not only was FMC7 negative but also had a dimmer expression of most of the B cell-associated antigens (CD20, CD79b, CD22, surface light chains). This finding was unusual and has not been reported earlier. Absence of SOX-11 expression probably explains the relatively indolent nature of the disease in our patient. ${ }^{4}$

The distinction between the clinically indolent CLL from MCL is important due to the aggressive course of MCL as well as differences in clinical management. Our case highlights the

\section{Learning points}

- Mantle cell lymphoma (MCL) can mimic chronic lymphocytic leukaemia (CLL) morphologically and immunophenotypically.

- Downregulation of B-cell-associated antigens, though typical of CLL, may also rarely occur in MCL.

- Evaluation for cyclin D1/CCND1 translocation by fluorescence in-situ hybridisation, as well as awareness of subtle immunophenotype variations, can help to distinguish CLL versus $\mathrm{MCL}$, with their clinically contrasting disease courses, survival and management strategies. relevance of evaluation for cyclin D1 immunohistochemistry or CCND1 translocation by FISH, as well as the importance of giving attention to subtle immunophenotypic variations (CD23/ CD200 negativity, dim CD43 and moderate $\operatorname{IgM} / \operatorname{IgD}$ positivity) in patients with a CLL-like immunophenotype, even if morphology is unremarkable. Awareness of these immunophenotypic aberrancies can prevent misdiagnosis and subsequent inappropriate management.

Contributors HV wrote the manuscript. SS proposed the concept and revised the manuscript. MUSS and AD were involved in the diagnosis and management of the patient and reviewed the manuscript.

Funding The authors have not declared a specific grant for this research from any funding agency in the public, commercial or not-for-profit sectors.

Competing interests None declared.

Patient consent for publication Obtained.

Provenance and peer review Not commissioned; externally peer reviewed.

ORCID iD

Sreejesh Sreedharanunni http://orcid.org/0000-0003-2626-4154

\section{REFERENCES}

1 Jain P, Wang M. Mantle cell lymphoma: 2019 update on the diagnosis, pathogenesis, prognostication, and management. Am J Hematol 2019;94:710-25.

2 Campo E, Ghia P, Montserrat E, et al. Chronic lymphocytic leukemia/small lymphocytic lymphoma. In: Swerdlow S, Campo E, Lee Harris N, et al, eds. WHO classification of tumor of haematopoietic and lymphoid tissues, Revised. 4th edn. Lyon, France: IARC, 2017.

3 Gao J, Peterson L, Nelson B, et al. Immunophenotypic variations in mantle cell lymphoma. Am J Clin Pathol 2009;132:699-706.

4 Narurkar R, Alkayem M, Liu D. Sox11 is a biomarker for cyclin D1-negative mantle cell lymphoma. Biomark Res 2016;4:6

Copyright 2020 BMJ Publishing Group. All rights reserved. For permission to reuse any of this content visit

https://www.bmj.com/company/products-services/rights-and-licensing/permissions/

BMJ Case Report Fellows may re-use this article for personal use and teaching without any further permission.

Become a Fellow of BMJ Case Reports today and you can:

- Submit as many cases as you like

- Enjoy fast sympathetic peer review and rapid publication of accepted articles

- Access all the published articles

Re-use any of the published material for personal use and teaching without further permission

Customer Service

If you have any further queries about your subscription, please contact our customer services team on +44 (0) 2071111105 or via email at support@bmj.com.

Visit casereports.bmj.com for more articles like this and to become a Fellow 